\title{
Increased expression of CENP-H gene in human oral squamous cell carcinomas harboring high-proliferative activity
}

\author{
HIDEO SHIGEISHI, KOICHIRO HIGASHIKAWA, SHIGEHIRO ONO, KUNIKO MIZUTA, \\ YOSHIAKI NINOMIYA, SHINGO YONEDA, MASAYUKI TAKI and NOBUYUKI KAMATA \\ Division of Cervico-Gnathostomatology, Department of Oral and Maxillofacial Surgery, Graduate School \\ of Biomedical Sciences, Hiroshima University, 1-2-3 Kasumi, Minami-ku, Hiroshima 734-8551, Japan
}

Received April 10, 2006; Accepted July 3, 2006

\begin{abstract}
We examined the expression of Centromere protein $\mathrm{H}(\mathrm{CENP}-\mathrm{H}) \mathrm{mRNA}$ in 38 oral squamous cell carcinomas (SCCs), 2 epithelial dysplasias and 5 normal gingivae using the real-time quantitative reverse transcription-polymerase chain reaction (RT-PCR). The mean expression level of CENP-H mRNA was higher in oral SCCs $(0.11 \pm 0.08)$ than epithelial dysplasias $(0.03 \pm 0.01)$ and normal gingivae $(0.027 \pm 0.01)$. The expression level of $C E N P-H$ mRNA was significantly higher in oral SCCs than normal gingivae (MannWhitney $\mathrm{U}$ test, $\mathrm{P}=0.005$ ). We also found a significant association between the level of $C E N P-H$ mRNA expression and clinical stage in oral SCCs (Mann-Whitney U test, $\mathrm{P}=0.04$ ). We next studied the expression of CENP-H in 17 oral SCCs immunohistochemically. A significant correlation between the expression levels of CENP-H protein and the Ki-67 labeling index was found (Mann-Whitney $\mathrm{U}$ test, $\mathrm{P}=0.005$ ). These results indicate that human CENP-H is closely linked to the increased or abnormal cell proliferation in malignant conditions.
\end{abstract}

\section{Introduction}

The kinetochore is a large complex protein structure that assembles in the centromeric region of each sister chromatid and is responsible for establishing and maintaining the connection with the mitotic spindle $(1,2)$. Kinetochore proteins can be divided into two groups: constitutive kinetocore proteins and faculative kinetochore proteins (3). Constitutive kinetocore proteins are found at centromeric foci throughout the cell cycle, comprising CENP-A, CENP-B and CENP-C (4-6). CENP-A is a central element of the human kinetochore protein concentrated in the inner kinetochore plate (4).

Correspondence to: Dr Hideo Shigeishi, Division of CervicoGnathostomatology, Department of Oral and Maxillofacial Surgery, Graduate School of Biomedical Sciences, Hiroshima University, 1-2-3 Kasumi, Minami-ku, Hiroshima 734-855, Japan

E-mail: shige@hiroshima-u.ac.jp

Key words: CENP-H, Ki-67, oral squamous cell carcinomas
CENP-C is also constitutively present in the inner kinetochore plate, which is closely associated with the centromeric heterochromatin (6). Faculative kinetochore proteins are localized in kinetochores tansiently during mitosis, comprising CENP-E and CENP-F $(7,8)$. CENP-F plays several important roles in mitotic events, including centromere/kinetochore maturation, chromosome alignment and segragation, and anaphase spindle stabilization $(9,10)$.

Human centromere protein-H (CENP-H) has been identified and discoverd as a constitutive component of the centromere (11). Confocal microscopic analysis of HeLa cells with antihuman CENP-H-specific antibody demonstrated that CENP-H is present at the inner kinetochore plate and colocalizes with CENP-A and CENP-C in both interphase and metaphase (12). The observation of a conditional loss of function mutant of CENP-H in the vertebrate cells revealed that CENP-H is a fundamental conponent of the active centromere complex (13). These identifications suggest that CENP-H might play an important role in kinetochore organization and function throught out the cell cycle.

Recently, overexpression of the CENP-H have been reported in human colorectal cancer tissues as well as cancer cell lines with chromosomal instability (14). However, no report exists on the expression of the CENP-H gene in oral squamous cell carcinomas. In this study, we examined the expression of human $C E N P-H$ mRNA and protein in oral squamous cell carcinomas to clarify the correlation between CENP-H expression and clinicopathological factors.

\section{Materials and methods}

Tissue samples. We examined 38 oral squamous cell carcinomas (SCCs), two epithelial dysplasias and five normal gingivas. Tumor tissues and specimens of normal gingivae were obtained with informed consent and approval from the institutional review board at Hiroshima University Dental Hospital (Japan) between 1995 and 2005. The mean age of the patients was 65.5 years. The oral SCC samples were derived from the tongue, upper gingiva, lower gingiva, buccal mucosa and floor of the mouth. The clinical staging was determined according to the International Union Against Cancer TNM classification (15). The primary tumors were classified histopathologically as well or moderately differentiated, based on the classification of the World Health Organization (16). 
For molecular analyses, tissue samples obtained at the time of surgery were frozen immediately in liquid nitrogen and stored at $-80^{\circ} \mathrm{C}$. We confirmed microscopically that the tumor specimens consisted mainly of carcinoma tissue and that the specimens of normal gingiva did not exhibit any tumor cell invasion or show significant inflammatory involvement.

RNA extraction and quantitative RT-PCR analysis. RNA was extracted with an RNAeasy Mini Kit (Qiagen, Hilden, Germany). One microgram of total-RNA was subjected to a reverse-transcriptase reaction using the First Strand cDNA Synthesis kit (Amersham Biosciences, Uppsala, Sweden). The quantitation of mRNA levels was carried out using a real-time fluorescence detection method according to the method of Eads et al (17). The fluorescence was detected by the laser detector of the Line Gene Fluorecent Quantitative Detection System (Bio Flux, Tokyo, Japan) and the detection was carried out by measuring the binding of a fluorescence dye, SYBR Green I, to double-stranded DNA. The PCR was run in microtubes in a volume of $20 \mu \mathrm{l}$. The reaction mixture contained $1.0 \mu \mathrm{g}$ of cDNA, $10 \mu \mathrm{l}$ of SYBR Green PCR Master Mix (TOYOBO, Osaka, Japan), and 10 pmol of each pair of oligonucleotide primers. The primer sequences were: CENP-H; 5'-TGCAAGAAAAGCAAATCGAA-3' (sense), 5'-ATCCCAAGATTCCTGCTGTG-3' (antisense), and G3PDH; 5'-ACCACAGTCCATGCCATCAC-3' (sense), 5'-TC CACCACCCTGTGGCTGTA-3' (antisense). The PCR program was as follows: initial melting at $95^{\circ} \mathrm{C}$ for $30 \mathrm{sec}$ followed by 40 cycles at $95^{\circ} \mathrm{C}$ for $15 \mathrm{sec}, 55^{\circ} \mathrm{C}$ for $10 \mathrm{sec}$ and $72^{\circ} \mathrm{C}$ for $15 \mathrm{sec}$. The quantitation of CENP-H mRNA relative to an internal control, G3PDH, was performed by the $\Delta \mathrm{Ct}$ method (18).

Immunohistochemistry. Avidin-biotin-peroxidase complex immunostaining was performed as described previously (19). CENP-H staining using an anti-CENP-H polyclonal antibody (Santa Cruz Biotechnology, Santa Cruz, CA) (diluted 1:100) was graded as high (at least $10 \%$ of tumor cells showed moderate to intense immunoreactivity) or low ( $<10 \%$ of tumor cells showed weak or no immunoreactivity). For the Ki-67 labeling index, an immunohistochemical analysis was performed using an anti-Ki-67 monoclonal antibody (Dako, Copenhagen, Denmark). The proportion of tumor cell nuclei stained by Ki-67 was calculated for each tumor in x 200 microscopic fields. All tumor cell nuclei stained brown above the background level, regardless of intensity, were considered positively stained. We presented the Ki-67 positive cell ratio as the number of tumor cells immunostained by $\mathrm{Ki}-67$ per more than 1000 carcinoma cells in each case (Ki-67 labeling index).

Statistical methods. The results of quantitative RT-PCR analysis were compared with the patients clinicopathological information using the Mann-Whitney $U$ test and Spearmans correlation coefficient by rank test. P-values of $<0.05$ were regarded as statistically significant.

\section{Results}

Expression of CENP-H mRNA in oral SCCs. We examined the expression of CENP-H mRNA in 38 oral SCCs and 2 epi-

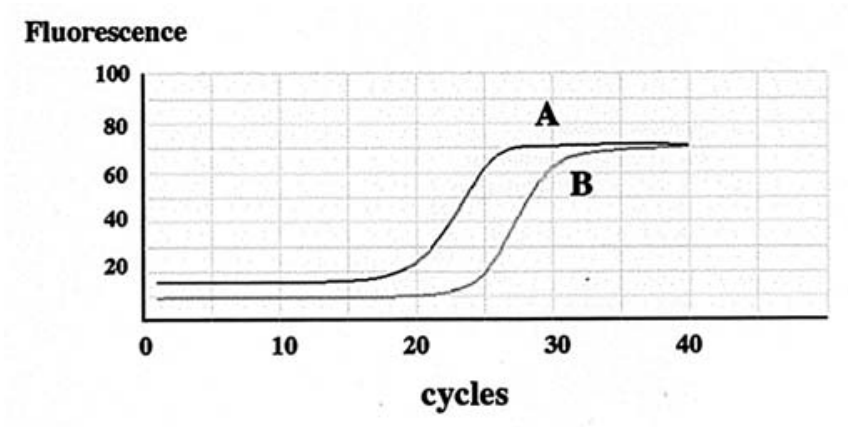

Figure 1. Amplification curves of real-time quantitative PCR analysis in an oral SCC sample: (A), G3PDH; (B), CENP-H. Fluorescence, fluorescence of SYBR Green I dye.

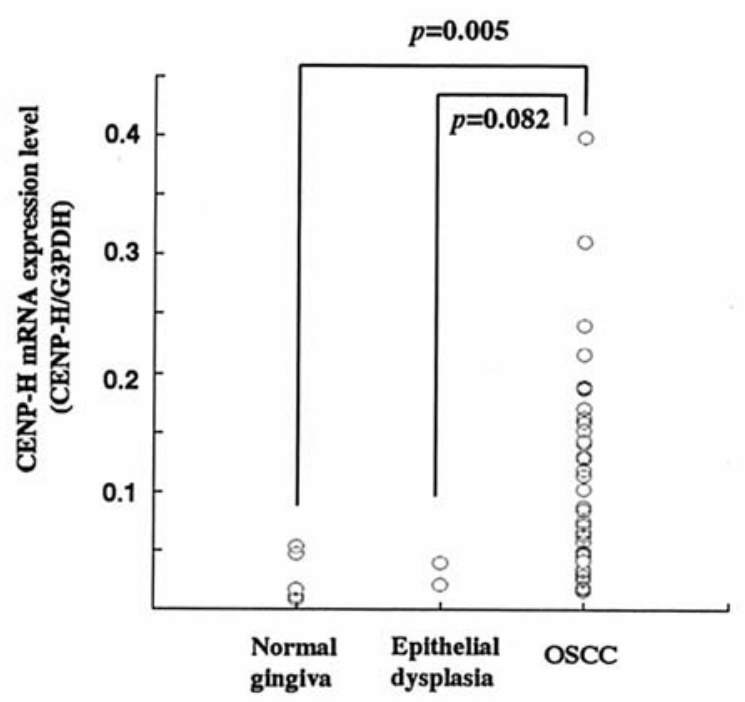

Figure 2. Levels of $C E N P-H$ mRNA expression in normal gingivas, epithelial dysplasias and oral SCCs: each point represents the $C E N P-H$ mRNA expression level. $C E N P-H$ mRNA expression levels were significantly higher in oral SCCs than normal gingivae (Mann-Whitney $\mathrm{U}$ test, $\mathrm{P}=0.005$ ).

thelial dysplasias and 5 normal gingivas by real-time RT-PCR. Results of a quantitative RT-PCR analysis of one oral SCC sample are shown in Fig. 1. The mean expression level of CENP-H mRNA was higher in oral SCCs $(0.11 \pm 0.08)$ than normal gingivae $(0.027 \pm 0.01)$ and epithelial dysplasias $(0.03 \pm 0.01)$ as shown in Fig. 2. The expression level of CENP-H mRNA was significantly higher in oral SCCs than normal gingivae (Mann-Whitney $U$ test, $\mathrm{P}=0.005$ ). In addition, oral SCCs showed high levels of $C E N P-H$ mRNA expression compared to epithelial dysplasias, although the difference was not significant (Mann-Whitney $\mathrm{U}$ test, $\mathrm{P}=0.082$ ). The expression of CENP-H mRNA was not correlated to clinicopathological factors such as age, gender, tumor type and tumor location. Data on $C E N P-H$ mRNA expression, tumor size, clinical stage and lymph node metastasis are summarized in Table I. The expression level of $C E N P-H$ mRNA was higher in stage III/IV oral SCCs than in stage I/II oral SCCs. A significant association was found between the level of CENP-H mRNA expression and clinical stage (Mann-Whitney U test, $\mathrm{P}=0.04$ ). The patients with larger tumors showed higher levels 
Table I. Expression of CENP- $H$ mRNA in OSCCs and its correlation with clinicopathological parameters.

\begin{tabular}{|c|c|c|c|}
\hline & \multirow[b]{2}{*}{ Case no. } & \multicolumn{2}{|c|}{$\begin{array}{c}\text { Expression level } \\
\text { of CENP-H }\end{array}$} \\
\hline & & Mean \pm SD & P-value \\
\hline \multicolumn{4}{|l|}{ Sex } \\
\hline Male & 21 & $0.12 \pm 0.02$ & 0.96 \\
\hline Female & 17 & $0.10 \pm 0.01$ & \\
\hline \multicolumn{4}{|l|}{ Site } \\
\hline Tongue & 15 & $0.091 \pm 0.014$ & 0.39 \\
\hline Upper gingiva & 5 & $0.17 \pm 0.047$ & \\
\hline Lower gingiva & 14 & $0.11 \pm 0.018$ & \\
\hline Buccal mucosa & 1 & 0.024 & \\
\hline Oral floor & 3 & $0.168 \pm 0.11$ & \\
\hline \multicolumn{4}{|l|}{ Histology ${ }^{b}$} \\
\hline Well & 13 & $0.102 \pm 0.015$ & 0.30 \\
\hline Moderate & 25 & $0.118 \pm 0.028$ & \\
\hline \multicolumn{4}{|l|}{ Tumor size } \\
\hline $\mathrm{T} 1$ & 4 & $0.043 \pm 0.01$ & 0.12 \\
\hline $\mathrm{T} 2$ & 17 & $0.095 \pm 0.014$ & \\
\hline $\mathrm{T} 3$ & 6 & $0.157 \pm 0.045$ & \\
\hline $\mathrm{T} 4$ & 11 & $0.140 \pm 0.031$ & \\
\hline \multicolumn{4}{|l|}{ Clinical stage ${ }^{b}$} \\
\hline $\mathrm{I}+\mathrm{II}$ & 17 & $0.077 \pm 0.01$ & 0.04 \\
\hline III+IV & 21 & $0.14 \pm 0.02$ & \\
\hline \multicolumn{4}{|l|}{$\begin{array}{l}\text { Lymph node } \\
\text { metastasis }\end{array}$} \\
\hline Positive & 12 & $0.11 \pm 0.018$ & 0.90 \\
\hline Negative & 26 & $0.12 \pm 0.018$ & \\
\hline
\end{tabular}

of $C E N P-H$ mRNA expression, although a significant association was not found.

Immunohistochemistry for CENP-H in oral SCCs. We next studied the expression of CENP-H in 17 oral SCCs immunohistochemically. The results of the immunohistochemical analysis reflected the levels of CENP-H mRNA expression obtained by quantitative RT-PCR. Normal gingivae showed weak or no immunoreactivity for CENP-H (Fig. 3A). Epithelial dysplasias showed weak CENP-H staining (data not shown). Seven (41\%) out of the 17 oral SCCs showed CENP-H positive staining, and the remaining $10(59 \%)$ cases were negative for CENP-H. Most of the oral SCCs with higher levels of CENP-H mRNA showed CENP-H positive staining (Fig. 3B).
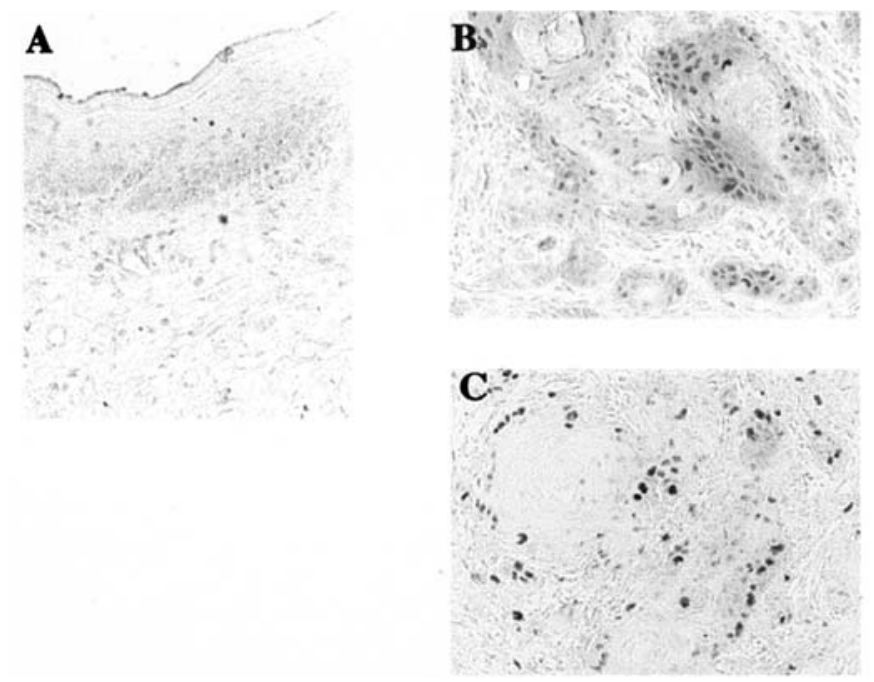

Figure 3. Immunohistochemistry for CENP-H and Ki-67 in oral SCC: (A), Expression of CENP-H in normal gingiva. (B), Expression of CENP-H in oral SCC. (C), Expression of Ki-67 in oral SCC.

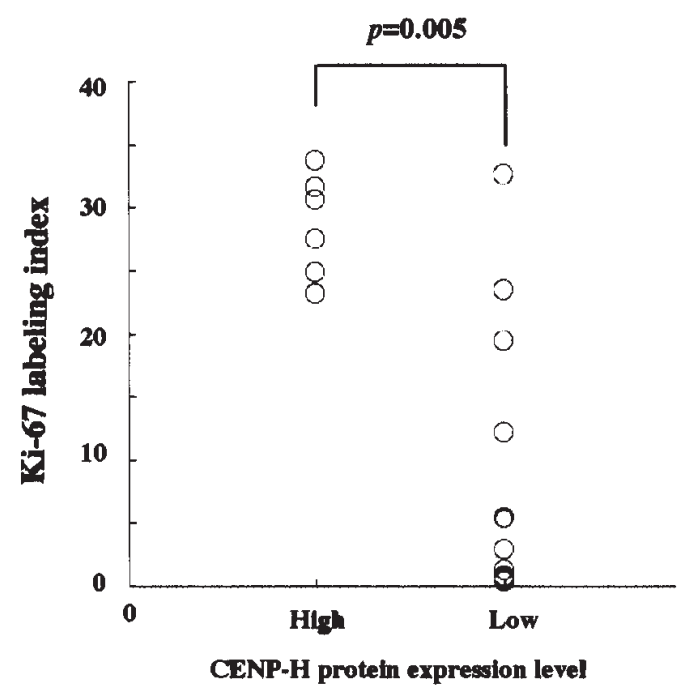

Figure 4. Correlation between CENP-H protein expression levels and Ki-67 labeling index and in oral SCCs. CENP-H expression levels were graded as high (at least $10 \%$ of tumor cells showed moderate to intense immunoreactivity) or low ( $<10 \%$ of tumor cells showed weak or no immunoreactivity). A significant correlation was found between the CENP-H protein expression levels and Ki-67 labeling index (Mann-Whitney $\mathrm{U}$ test, $\mathrm{P}=0.005$ ).

Immunohistochemistry for Ki-67 in oral SCCs. We further examined the expression of Ki-67 in oral SCCs immunohistochemically to investigate the correlation between CENP-H expression and proliferating activity. All the normal gingivae and epithelial dysplasias had a low Ki-67 labeling index. The index was compared with the expression levels of CENP-H protein in the tumors. The average Ki-67 labeling index in the cases with CENP-H high expression and with low expression was $28.6 \pm 4.1$ and $8.76 \pm 10.8$, respectively, indicating a significant correlation between the Ki-67 labeling index and CENP-H expression in oral SCCs (Mann-Whitney U test, $\mathrm{P}=0.005$ ) (Fig. 4). 


\section{Discussion}

Chromosome segregation in mitosis depends on kinetochores, complex protein structures that assemble at the centromeres of chromosomes (10). Kinetochores play a significant role in the check-point mechanism that delays the onset of anaphase until all the chromosomes achieve bipolar attachments (20). Recently, a number of kinetochore components have been identified. CENP-H is a protein of the fundamental components of the centromere-kinetochore complex throughout the cell cycle, localizing outside centromeric heterochromatin. CENP-A and CENP-C, constitutive kinetochore proteins, localize to the inner kinetochore plate $(4,6)$. CENP-H colocalizes with CENP-A and CENP-C in both interphase and metaphase $(11,12)$. CENP-H is also capable of interacting with mitotic centromere associated kinesin (MCAK), which is one of the kinetochore proteins localize to the centromeric heterochromatin, as well as to the outer face of the kinetochore $(12,21)$. Although these observations suggest that CENP-H plays an important role in kinetochore assembly and interactions between inner kinetochore plate and outer plate, the functions of CENP-H are not well understood.

CENP-F is a faculative kinetochore protein that gradually accumulates during the $\mathrm{G} 2$ and $\mathrm{M}$ phases, localizing in the kinetochore region of the centromeres and in the spindle midzone $(2,22)$. CENP-F is able to interact with CENP-E and the spindle check-point component Bub1 (23). CENP-F plays a significant role in kinetochore assembly and the spindle checkpoint. Esguerra et al reported a correlation between the expression of CENP-F and the Ki-67 labeling index in oral SCCs (24). We have also reported that $C E N P-F$ mRNA levels were higher in patients with oral SCCs harboring lymph node metastasis than in cases without metastasis (25). Furthermore, oral SCC patients with lower CENP-F mRNA levels had a better survival rate than those with higher CENP-F mRNA levels (25). We also reported a significant correlation between $C E N P-F / B u b l$ expression and the Ki-67 labeling index in salivary gland tumors $(26,27)$. These results suggest the usefulness of the $C E N P-F$ gene as an additional diagnostic tool for oral SCCs and salivary gland tumors.

In this study, we first analyzed the expression of the $C E N P-H$ gene in human oral SCC patients. We found that levels of $C E N P-H$ mRNA were higher in oral SCCs than in epithelial dysplasias and normal gingivae. We also found an association between $C E N P-H$ mRNA expression and clinical stage in oral SCCs. Furthermore, we demonstrated a significant association between the expression level of CENP-H protein and the Ki-67 labeling index which has been used as a proliferation marker of oral squamous cell carcinomas $(28,29)$. These results indicate that expression of the human $C E N P-H$ gene is associated with tumor-proliferating activity in human oral SCCs. Furthermore, we investigated an association between expression levels of $C E N P-H$ mRNA and oral SCC patients survival rates. Oral SCC patients with lower CENP-H mRNA levels had a better survival rate than those with higher $C E N P-H$ mRNA levels (Shigeishi et al, unpublished data).

Autoantibodies to centromere protein have been observed in many patients with malignant tumors or rheumatic disorders $(30,31)$. Recently, anti-CENP-H antibodies were identified in the sera of patients with Sjogren's syndrome (32). The observation suggest that anti-CENP-H antibody is a useful marker for Sjogren's syndrome. However, the clinical significance of anti-CENP-H antibody has not been investigated in human cancers. The identification of anti-CENP-H antibody in oral SCC patients is needed to confirm the increased expression of CENP-H in oral SCCs.

The identification of a specific factor for predicting clinical outcome in cases of oral SCCs would be helpful for selecting effective treatments. The present study suggests the usefulness of the $C E N P-H$ gene as an additional diagnostic tool for oral SCCs.

\section{Acknowledgements}

This study was supported by a Grant-in-aid from the Japanese Ministry of Education, Culture, Sports and Technology.

\section{References}

1. Nicklas RB: How cells get the right chromosomes. Science 275: 632-637, 1997.

2. Rieder CL and Salmon ED: The vertebrate cell kinetochore and its roles during mitosis. Trends Cell Biol 8: 310-318, 1998.

3. Saffery R, Irvine DV, Griffiths B, Kalitsis P, Wordeman L and Choo KH: Human centromeres and neocentromeres show identical distribution patterns of $>20$ functionally important kinetochoreassociated proteins. Hum Mol Genet 9: 175-185, 2000.

4. Palmer DK, O'Day K, Trong HL, Charbonneau H and Margolis RL: Purification of the centromere-specific protein CENP-A and demonstration that it is a distinctive histone. Proc Natl Acad Sci USA 88: 3734-3738, 1991.

5. Masumoto H, Masukata H, Muro Y, Nozaki N and Okazaki T: A human centromere antigen (CENP-B) interacts with a short specific sequence in alphoid DNA, a human centromeric satellite. J Cell Biol 109: 1963-1973, 1989.

6. Saitoh H, Tomkiel J, Cooke CA, Ratrie H III, Maurer M, Rothfield NF and Earnshaw WC: CENP-C, an autoantigen in scleroderma, is a component of the human inner kinetochore plate. Cell 70: 115-125, 1992.

7. Yen TJ, Li G, Schaar BT, Szilak I and Cleveland DW: CENP-E is a putative kinetochore motor that accumulates just before mitosis. Nature 359: 536-539, 1992.

8. Liao H, Winkfein RJ, Mack G, Rattner JB and Yen TJ: CENP-F is a protein of the nuclear matrix that assembles onto kinetochores at late G2 and is rapidly degraded after mitosis. J Cell Biol 130: 507-518, 1995

9. Yang ZY, Guo J, Li N, Qian M, Wang SN and Zhu XL: Mitosin/ CENP-F is a conserved kinetochore protein subjected to cytoplasmic dynein-mediated poleward transport. Cell Res 13: 275-283, 2003.

10. Amon A: The spindle check-point. Curr Opin Genet Dev 9: 69-75, 1999.

11. Sugata N, Munekata E and Todokoro K: Characterization of a novel kinetochore protein, CENP-H. J Biol Chem 274: 27343-27346, 1999

12. Sugata N, Li S, Earnshaw WC, Yen TJ, Yoda K, Masumoto H, Munekata E, Warburton PE and Todokoro K: Human CENP-H multimers colocalize with CENP-A and CENP-C at active centromere-kinetochore complexes. Hum Mol Genet 9: 29192926, 2000.

13. Fukagawa T, Mikami Y, Nishihashi A, Regnier V, Haraguchi T, Hiraoka Y, Sugata N, Todokoro K, Brown W and Ikemura T: CENP-H, a constitutive centromere component, is required for centromere targeting of CENP-C in vertebrate cells. EMBO J 20: 4603-4617, 2001.

14. Tomonaga T, Matsushita K, Ishibashi M, Nezu M, Shimada H, Ochiai T, Yoda $\mathrm{K}$ and Nomura F: Centromere protein $\mathrm{H}$ is upregulated in primary human colorectal cancer and its overexpression induces aneuploidy. Cancer Res 65: 4683-4689, 2005.

15. Sobin LH and Wittekind C (eds): TNM classification of malignant tumors. 5th edition. John Wiley \& Sons, New York, 1997.

16. World Health Organozation: International histological classification of tumors. 2nd edition. Springer, Berlin, 1998. 
17. Eads CA, Danenberg KD, Kawakami K, Saltz LB, Danenberg PV and Laird PW: $\mathrm{CpG}$ island hypermethylation in human colorectal tumors is not associated with DNA methyltransferase overexpression. Cancer Res 59: 2302-2306, 1999.

18. Tanaka S, Kobayashi I, Utsuki S, Oka H, Fujii K, Watanabe T, Nagashima T and Hori T: O6-methylguanine-DNA methyltranspherase gene expression in gliomas by means of real-time quantitative RT-PCR and clinical response to nitrosoureas. Int $\mathbf{J}$ Cancer 103: 67-72, 2003.

19. Kuniyasu H, Oue N, Shigeishi H, Ito R, Kato Y, Yokozaki H and Yasui W: Prospective study of Ki-67 labeling index in the mucosa adjacent to cancer as a marker for colorectal cancer metastasis. J Exp Clin Cancer Res 20: 543-548, 2001.

20. Rudner AD and Murray AW: The spindle assembly checkpoint. Curr Opin Cell Biol 8: 773-780, 1996.

21. Wordeman L and Mitchison TJ: Identification and partial characterization of mitotic centromere-associated kinesin, a kinesin-related protein that associates with centromeres during mitosis. J Cell Biol 128: 95-104, 1995.

22. Mancini MA, He D, Ouspenski II and Brinkley BR: Dynamic continuity of nuclear and mitotic matrix proteins in the cell cycle. J Cell Biochem 62: 158-164, 1996.

23. Chan GK, Schaar BT and Yen TJ: Characterization of the kinetochore binding domain of CENP-E reveals interactions with the kinetochore proteins CENP-F and hBUBR1. J Cell Biol 143: 49-63, 1998

24. Esguerra RL, Jia L, Kaneko T, Sakamoto K, Okada N and Takagi M: Immunohistochemical analysis of centromere protein $\mathrm{F}$ expression in buccal and gingival squamous cell carcinoma. Pathol Int 54: 82-89, 2004
25. Shigeishi H, Mizuta K, Higashikawa K, Shimasue H, Ohta K, Ono S, Sugiyama M and Kamata N: Correlation of CENP-F mRNA expression and lymph node metastasis in oral squamous cell carcinomas. Jpn J Oral Maxillofac Surg 51: 77-81, 2005.

26. Shigeishi H, Mizuta K, Higashikawa K, Yoneda S, Ono S and Kamata N: Correlation of CENP-F gene expression with tumorproliferating activity in human salivary gland tumors. Oral Oncol 41: 716-722, 2005.

27. Shigeishi H, Yoneda S, Taki M, Nobumori T, Ohta K, Higashikawa K, Yasui W and Kamata N: Correlation of human Bub1 expression with tumor-proliferating activity in salivary gland tumors. Oncol Rep 15: 933-938, 2006.

28. Girod SC, Krueger G and Pape HD: p53 and Ki 67 expression in preneoplastic and neoplastic lesions of the oral mucosa. Int $\mathbf{J}$ Oral Maxillofac Surg 22: 285-288, 1993.

29. Xie X, De Angelis P, Clausen OP and Boysen M: Prognostic significance of proliferative and apoptotic markers in oral tongue squamous cell carcinomas. Oral Oncol 35: 502-509, 1999.

30. Abu-Shakra M, Buskila D, Ehrenfeld M, Conrad K and Shoenfeld Y: Cancer and autoimmunity: autoimmune and rheumatic features in patients with malignancies. Ann Rheum Dis 60: 433-441, 2001.

31. Rattner JB, Rees J, Whitehead CM, Casiano CA, Tan EM, Humbel RL, Conrad K and Fritzler MJ: High frequency of neoplasia in patients with autoantibodies to centromere protein CENP-F. Clin Invest Med 20: 308-319, 1997.

32. Hsu TC, Chang CH, Lin MC, Liu ST, Yen TJ and Tsay GJ: Anti-CENP-H antibodies in patients with Sjogren's syndrome. Rheumatol Int 26: 298-303, 2006. 